Clinical Image

\section{Corneal stromal abscess and anterior uveitis in a pet goat}

\author{
Panagiotis D Katsoulos* and Konstantinos S Themistokleous \\ Clinic of Farm Animals, School of Veterinary Medicine, Aristotle University of Thessaloniki, Greece
}

\section{More Information}

*Address for Correspondence:

Panagiotis D Katsoulos, Clinic of Farm Animals, Faculty of Veterinary Medicine, Aristotle University of Thessaloniki, St. Voutyra 11, GR-54627, Thessaloniki, Greece, Email: katsoulo@vet.auth.gr

Submitted: September 08, 2021

Approved: September 20, 2021

Published: September 21, 2021

How to cite this article: Katsoulos PD, Themistokleous KS. Corneal stromal abscess and anterior uveitis in a pet goat. Insights Vet Sci. 2021; 5: 022-023.

DOI: 10.29328/journal.ivs.1001031

Copyright: (c) 2021 Katsoulos PD, et al. This is an open access article distributed under the Creative Commons Attribution License, which permits unrestricted use, distribution, and reproduction in any medium, provided the original work is properly cited.

(A) Check for updates OPEn ACCESS eye drops to be administered twice a day for the next 4 days.
The treatment was not successful and the eye's condition deteriorated the following days.

The clinical examination of the eye revealed pain, photophobia, dense peripheral corneal vascularization, corneal edema, miosis and a paraxial stromal abscess with white creamy appearance (Figure 1). Fluorescein test was negative and Schirmer tear test was $16 \mathrm{~mm} / \mathrm{min}$, within normal range [1].

The diagnosis was stromal corneal abscess and anterior uveitis.

The animal was treated with

1. Third eyelid flap (Figure 2) for 15 days [2],

2. Topical administration of a commercial ophthalmic

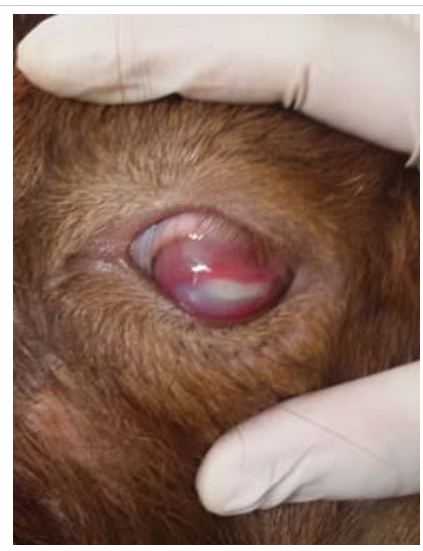

Figure 1: Dense peripheral corneal vascularization, corneal edema and a paraxial corneal stromal abscess with white creamy appearance at the left eye of the pet goat.

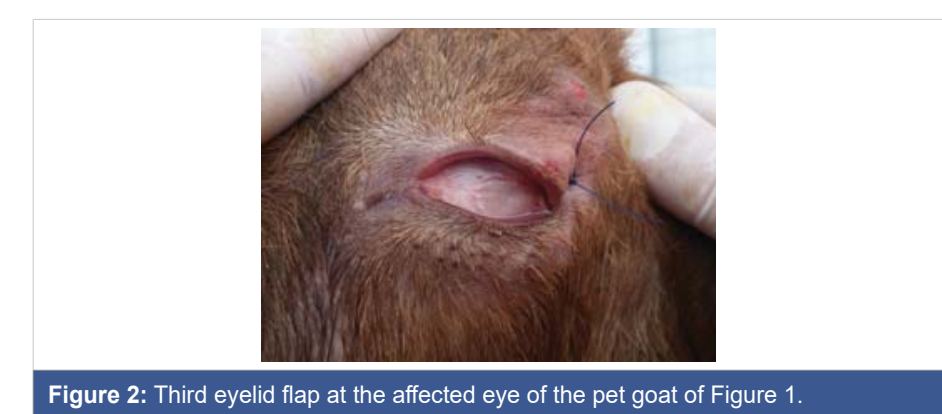

antibiotic-corticosteroid solution containing chloramphenicol (0.5\%) and dexamethasone sodium phosphate $(0.1 \%)$ (Dispersadron- $\mathrm{C}^{\odot}$; Novartis, Hellas), 1 drop 3 times per day for 15 days,

3. Topical administration of mydriatic eye drops containing cyclopentolate $1 \%$ (Cyclogyl $^{\odot}$; Alco, Hellas), 1 drop twice per day for 5 days,

4. Topical administration of an eye lubricant gel containing carbomer $0.2 \%$ (Liposic $^{\odot}$; Pharmaswiss, Hellas) and

5. Intramuscular administration of oxytetracycline long acting at the dose rate of $10 \mathrm{mg} / \mathrm{kg}$ body weight every $48 \mathrm{~h}$ for 8 days

The third eyelid flap was removed after 15 days; the vision was completely restored, the pupillary light reflex was normal and the eye had slight corneal opacity (Figure 3a) 
and micro-vascularization (Figure 3b). No other medication was prescribed thereafter, and the remaining slight corneal lesions were completely resolved 2 weeks after.



Figure 3: Slight corneal opacity (a) and micro-vascularization (b) at the left eye of the pet goat of Figure 1 after the removal of the third eyelid flap ( 15 days after the onset of treatment).

\section{Conflict of interest}

The authors report no conflicts of interest. The authors alone are responsible for the content and writing of this clinical image.

\section{References}

1. Dedousi A, Karatzia MA, Katsoulos PD. Reference values of Schirmer tear test in sheep and the effect of season on the test results. Acta Vet Hung. 2019; 67: 553-560.

PubMed: https://pubmed.ncbi.nlm.nih.gov/31842602/

2. De Melo D, Lopes J, Costa A, Veloso J, Alberto Carlos R, et al. Bullous Keratopathy in a dog treated with Third Eyelid Flap and Autologous Serum Eye Drops. Acta Sci Vet. 2020; 48. 